\title{
Sonographic Assessment of the Fetal Thoracic Length (FTL) as a Predictor of Gestational Age (GA) in Nigerian Population
}

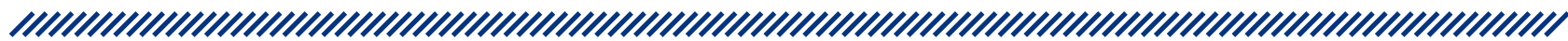

1 Joseph Dimas

2 Nwobi Ivor

3 Wiam Elshami

4 Joseph Dlama

1 Department of Radiology, Federal Medical Centre Katsina, Katsina State

2 Department of Radiography, University of Maiduguri

3 Department of Medical Diagnostic Imaging, University of Sharjah, Sharjah United Arab Emirates

4 Department of Radiology, Abubakar Tafawa Balewa University Teaching Hospital Bauchi

\section{Abstract}

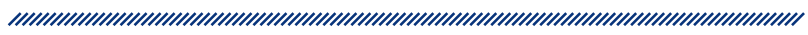

Background: The ultrasound machines used in our locality are programmed with software of non-indigenous normative values; furthermore, as pregnancy advances the accuracy of most biometric parameters in predicting GA varies due to racial morphological difference and error increases, hence the need for this study.

Purpose: To determine local (black race) sonographic FTL normative values and to compare the values with that of the Caucasian population.

Material and Methods: Women with a singleton pregnancy that was conceived naturally and who met the individual inclusion criteria were recruited consecutively. The Helsinki declaration of 1975 was considered. A prospective cross-sectional study was conducted in the Federal Medical Center Azare, Bauchi. The study in- volved 253 women from 16 to 38 weeks of gestation. A $2 \mathrm{D}$ ultrasound scan was used to measure the FTL (that is from the root of the neck to the diaphragm) at the level of the four-chamber view.

Results: Normal values of the FTL were developed and showed a linear and statistically significant correlation with the weeks of gestation $(r 2=0.81, P \leq 0.001)$. The FTL has a growth rate of $0.182 \mathrm{~cm}$ per week.

Conclusion: There is no statistically significant difference between the FTL of the population under study (black population) and that of the Caucasian population. Hence, the use of Caucasian FTL on black race is a valid estimate of GA. And the GA predictive equation is; $y=3.61 x+11.95$. Where $y=$ gestational age in weeks and $\mathrm{x}=$ thoracic length.

Keywords: Fetal thoracic length (FTL), gestational age (GA), four-chamber view, ultrasound scan.

Article received: 01.07.2017.

Article accepted: 07.10.2018.

DOI: $10.24141 / 1 / 4 / 2 / 8$

Corresponding author:

Joseph Dlama

Department of Radiology, Abubakar Tafawa Balewa University Teaching Hospital, Bauchi, Nigeria

Email: josephdlama@gmail.com

Tel: +234 8130582721 


\section{Introduction}

Gestational age (GA) refers to the duration of pregnancy from a woman's last menstrual period (LMP) which is indicated in weeks and/or days. This can be estimated from a woman's LMP history, symphysis-fundus height measurement and ultrasound measurements. However, the first two have a tendency for enormous error unlike the ultrasound measurements (1).

Fetal ultrasound measurements have a variety of scientific and clinical applications. These include studying normal and abnormal fetal growth, placenta placement, checking multiple gestations, age of a fetus, assessing the effects of drugs and teratogenic agents on fetal growth, assessing intra-uterine growth anomaly, etc. $(2,3)$.

Estimation of gestational age is paramount in the management of pregnant women. However, fetal ultrasound measurement cannot provide a reliable estimate of gestational age or conception dates (4). This is because there are numerous potential sources of error in assigning gestational age to pregnancy (5). Besides, as pregnancy advances, the accuracy of most biometric parameters in predicting GA varies and error increases (6 - 8).

There are established parameters that can be used to determine fetal growth and GA and they are: crownrump length $(\mathrm{CRL})$, head circumference $(\mathrm{HC})$, abdominal circumference (AC), bi-parietal diameter (BPD, thoracic circumference, occipito-frontal diameter and femur length (FL). Other parameters are: fetal neck circumference, fetal chest circumference, fetal kidney length, fetal humerus, fetal liver and axial transverse diameter of the fetal foramen magnum. Some of these parameters not only determine fetal growth but weight as well (9-12).

The accuracy in predicting GA using various ultrasound fetal parameters decreases as pregnancy advances; therefore, it is necessary to attempt unexplored fetal body parts or regions among the different races and populations to check if GA accuracy would improve. Therefore, due to recent advances in ultrasound technology and the established landmark of four-chamber view, 2D sonographic measurement of the FTL will in no doubt be a proper parameter in estimating GA. Fetal thoracic length measurement has been performed on the Caucasian population (13); however, this study focused on the black population. The aim of this study was to develop normal sonographic values of the fetal thoracic length in the black population and compare these values with the Caucasian fetal thoracic length which will determine whether the Caucasian fetal thoracic length is valid for use on the local population under study.

\section{Material and Methods}

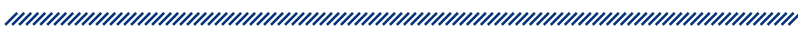

This study was a single-centre, multiethnic population pilot study conducted between 2013 and 2014 in the Federal Medical Center (FMC) in Azare town, Bauch state, Northeastern Nigeria. The study was approved by the ethical committee of the Federal Medical Center Azare. In addition, the Ethical standard in accordance with the Helsinki declaration of 1975 as revised in 2000 was adopted (14) and every participant gave their written consent for the participation in the study.

A prospective cross-sectional study was used. Two hundred and fifty-three eligible women consented to participate in the study. All recruited participants were with a singleton pregnancy that was conceived naturally and who met the inclusion criteria, consecutively selected from 16 to 38 weeks of gestation. Ultrasound system Sonoace 3200 (Manufactured by Medison, Seoul, South Korea), curvilinear abdominal transducer of 3.5MHz, 2D ultrasound scan was used for all the fetal measurements.

The true GA was defined by the woman's LMP determined: (i) the date was certain; (ii) she had a regular menstrual cycle; (iii) LMP was in agreement within one week of Gold standard measurement of AC, BPD, FL as estimate of GA.

The period of gestation from which measurements were obtained was divided into 23 weeks. The FTL, AC, $B P D$, and FL of each fetus with their corresponding gestational age (GA) were measured and their corresponding GA obtained.

Fetal thoracic length (FTL): Sonographic assessment of uncomplicated singleton pregnancies from 16-38 weeks' gestation was done. At the level of the fourchamber view, the thoracic length (TL); from the root of the neck to the diaphragm was measured $(13,15,16)$.

Abdominal circumference $(A C)$ : The measurements of the fetal abdomen were taken in a cross-sectional view 
(as close as possible to a circle), with the umbilical vein in the anterior third of the abdomen (at the level of the portal sinus) and the stomach bubble visible. The operator was instructed to avoid applying too much pressure with the transducer as this can distort the circular shape of the fetal abdomen. The abdomen had to fill at least $30 \%$ of the monitor screen; the spine preferably had to be positioned at either 3 or 9 o'clock to avoid internal shadowing; and the kidneys and bladder did not have to be visible. For the measurements, the contour of the ellipse was placed on the outer border of the abdomen $(17,18)$.

Biparietal diameter (BPD): Head measurements were done by taking an axial view at the level of the thalami, with an angle of insonation as close as possible to $90^{\circ}$. The head had to be oval in shape, symmetrical, centrally positioned and filling at least $30 \%$ of the monitor. The midline echo (representing the falx cerebri) had to be broken anteriorly, at one-third of its length, by the cavum septi pellucidi. The thalami had to be located symmetrically on either side of the midline. Calipers were then placed on the outer to inner border of the parietal bones at the widest or longest part of the skull for the $\operatorname{BPD}(17,19)$.

Femur length (FL): The FL was measured using a longitudinal view of the fetal thigh closest to the probe and with the femur as close as possible to the horizontal plane. The angle of insonation of the ultrasound beam was approximately $90^{\circ}$ with the full length of the bone visualized, unobscured by shadowing from adjacent bony parts, and the femur had to fill at least $30 \%$ of the monitor screen. The intersection of the calipers was placed on the outer borders of the edges of the femoral diaphysis (outer to outer) ensuring clear femoral edges $(8,17)$.

From the measured parameters, the average gestational age (AGA) for the respective FTL was obtained and used as a gold standard (20).

\section{Statistical analysis}

All women biometric variables and permutations to build models to predict GA were done. Correlation analysis was done to show relationship between thoracic length and other gestational age parameters. 5th, 50th and 95th percentiles and regression equations were ranked based upon minimization of the mean prediction error, goodness of fit and model complexity. Student T-test was performed to compare the mean thoracic length values of the population under study (black population) with the Caucasian population.

\section{Results}

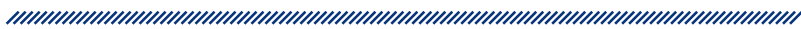

Table 1 shows age frequency distribution of all participants. The subjects range from ages 15 to 45 years. The highest percentage came from ages 20 to 24 years (36.8\%), and the lowest from ages 40 to 45 years (3.6\%).

Table 2 shows the frequency distribution according to parity was however obtained. Nulliparous women ranked highest with 63 (24.9\%), followed by women with parity of two (17.8\%).

Table 3 shows the frequency distribution according to the tribe. The multiethnic diversity is shown; however, the Hausa tribe has the highest percentage with 157 (62.1\%), followed by Fulani with 59 (23.3\%).

Table 4 shows the frequency distribution according to weeks of gestation with predictive percentiles.

Table 5 shows a comparison between the 50th percentile of FTL in this study (black population) and of the Caucasian population.

Figure 1 shows the scatter diagram showing the relationship between FTL and BPD. There is a highly positive correlation and statistically significant correlation is noted between FTL and BPD $\left(r^{2}=0.778, P \leq 0.001\right)$.

Figure 2 shows the scatter diagram of FTL against AC. There is a highly positive correlation and statistically significant correlation is noted between the FTL and AC $\left(r^{2}=0.752, P \leq 0.001\right)$.

Figure 3 shows the scatter diagram of FTL against FL. There is a highly positive and statistically correlation noted between the FTL and FL $\left(r^{2}=0.708, P \leq 0.001\right)$.

Figure 4 shows the scatter diagram of FTL against weeks of gestation. There is a high correlation and statistically significant correlation is noted between the weeks of gestation and the FTL $\left(r^{2}=0.807, P \leq 0.001\right)$.

Student T-test (two tail) showed that there was no difference between the mean of the measured fetal thoracic length of the black population and that of the Caucasian population $(P \leq 0.394>0.05)$. 


\begin{tabular}{|c|c|c|}
\hline Age & Frequency & Percentage \\
\hline $15-19$ & 38 & 15.0 \\
\hline $20-24$ & 93 & 36.8 \\
\hline $25-29$ & 60 & 23.7 \\
\hline $30-34$ & 38 & 15.0 \\
\hline $35-39$ & 15 & 5.90 \\
\hline $40-45$ & 9 & 3.60 \\
\hline Total & 253 & 100 \\
\hline
\end{tabular}

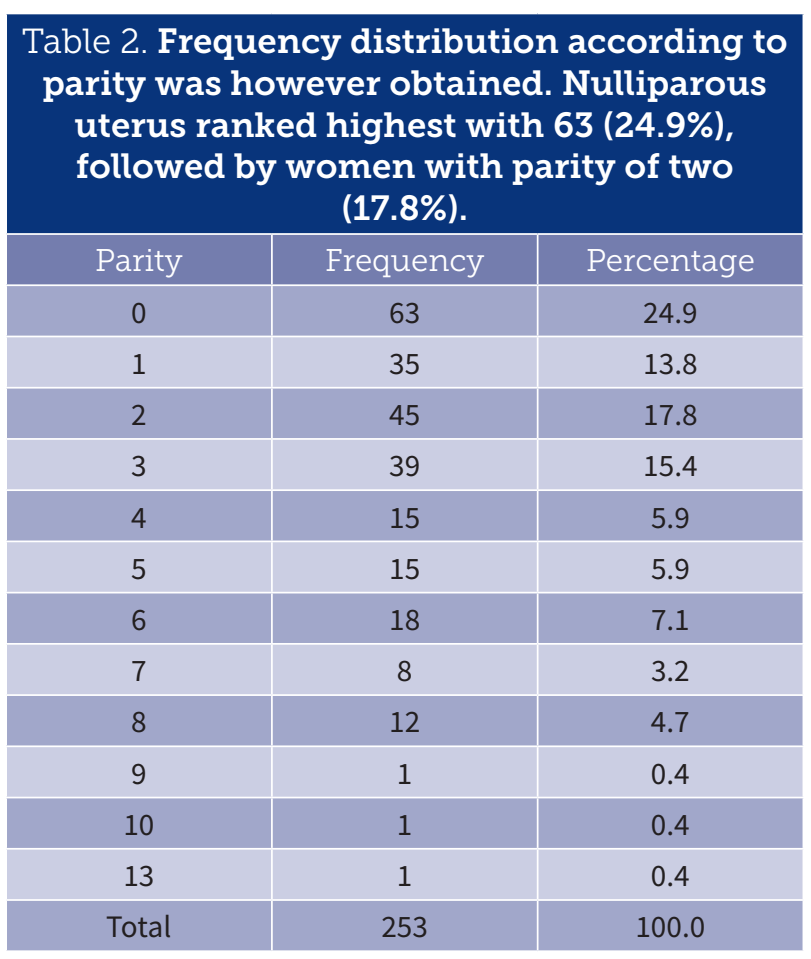

\section{Discussion}

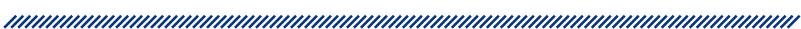

The study involved 253 pregnant women between the ages of 15 and 45 years (Table 1 ). The majority of the participants were women between 20 and 24 years of age. The minimum age of 15 years shows that girls in the region marry at a very young age. Early marriages in Nigeria are associated with some socio-economic factors such as poverty, illiteracy, and religious beliefs (21). The majority of the participants were nulliparous

\begin{tabular}{|c|c|c|}
\hline Tribe & Frequency & Percentage \\
\hline Bade & 1 & 0.4 \\
\hline Bura & 1 & 0.4 \\
\hline Daba & 1 & 0.4 \\
\hline Dajju & 1 & 0.4 \\
\hline Fulani & 59 & 23.3 \\
\hline Hausa & 157 & 62.1 \\
\hline Igbo & 9 & 3.6 \\
\hline Jukun & 1 & 0.4 \\
\hline Kanuri & 12 & 4.7 \\
\hline Kilba & 1 & 0.4 \\
\hline Kogi & 1 & 0.4 \\
\hline Mandara & 1 & 0.4 \\
\hline Marghi & 1 & 0.4 \\
\hline Nakere & 1 & 0.4 \\
\hline Shuwa & 1 & 0.4 \\
\hline Waja & 1 & 0.4 \\
\hline Yabe & 1 & 0.4 \\
\hline Yobe & 1 & 0.4 \\
\hline Yoruba & 2 & 0.8 \\
\hline Total & 253 & 100.0 \\
\hline
\end{tabular}

(Table 2). Table 3 shows frequency distribution according to the tribes that participated in the study. The tribe that dominated the study was the Hausa (62.1\%) followed by the Fulani (23.3\%). Therefore, this explains that the major tribes of the inhabitants of the region under study (Azare, Bauchi state) are Hausa and Fulani. However, Table 3 also shows the diverse ethnic groups in the country even though it was just a few that were represented in the study.

Table 4 shows the frequency distribution according to weeks of gestation with predictive percentiles, and table 5 shows the 50th percentile of the population under study and the Caucasian population. Student T-test showed that there is no significant racial difference in the FTL of black population under study and that of the Caucasian population $(P \leq 0.394>0.05)$ which is not in agreement with the findings of Matrobattista et al. (22) 


\section{Table 4. Frequency distribution according to weeks of gestation with predictive percentiles.}

\begin{tabular}{|c|c|c|c|c|}
\hline Week & Frequency & $5^{\text {th }}$ percentile & $50^{\text {th }}$ percentile & $95^{\text {th }}$ percentile \\
\hline 16 & 6 & 1.3 & 2.1 & 2.8 \\
\hline 17 & 8 & 1.5 & 2.3 & 3.1 \\
\hline 18 & 6 & 1.7 & 2.5 & 3.2 \\
\hline 19 & 7 & 1.8 & 2.6 & 3.4 \\
\hline 20 & 10 & 2.1 & 2.9 & 3.7 \\
\hline 21 & 21 & 2.2 & 3.2 & 4.0 \\
\hline 22 & 24 & 2.6 & 3.6 & 4.3 \\
\hline 23 & 7 & 2.8 & 3.8 & 4.5 \\
\hline 24 & 12 & 2.9 & 3.9 & 4.8 \\
\hline 25 & 10 & 3.1 & 4.1 & 5.0 \\
\hline 26 & 10 & 3.3 & 4.3 & 5.3 \\
\hline 27 & 11 & 3.4 & 4.4 & 5.6 \\
\hline 28 & 13 & 3.6 & 4.7 & 5.9 \\
\hline 29 & 13 & 3.8 & 5.0 & 6.2 \\
\hline 30 & 10 & 3.9 & 5.2 & 6.5 \\
\hline 31 & 12 & 4.1 & 5.4 & 6.7 \\
\hline 32 & 15 & 4.2 & 5.7 & 7.2 \\
\hline 33 & 10 & 4.3 & 5.8 & 7.3 \\
\hline 34 & 11 & 4.4 & 5.9 & 7.4 \\
\hline 35 & 10 & 4.5 & 6.0 & 7.6 \\
\hline 36 & 10 & 4.6 & 6.2 & 7.7 \\
\hline 37 & 9 & 4.7 & 6.3 & 7.8 \\
\hline 38 & 8 & 4.8 & 6.4 & 7.9 \\
\hline Total & 253 & & & \\
\hline
\end{tabular}

Table 5. Comparison between the 50th percentile of FTL in this study (black population) and of the Caucasian population. 50th PERCENTILE

\begin{tabular}{|c|c|c|}
\hline Weeks & $\begin{array}{c}\text { Black } \\
\text { population }\end{array}$ & $\begin{array}{c}\text { Caucasian } \\
\text { population }\end{array}$ \\
\hline 16 & 2.1 & 2.0 \\
\hline 17 & 2.3 & 2.2 \\
\hline 18 & 2.5 & 2.4 \\
\hline 19 & 2.6 & 2.7 \\
\hline 20 & 2.9 & 2.8 \\
\hline 21 & 3.2 & 3.0 \\
\hline 22 & 3.6 & 3.2 \\
\hline 23 & 3.8 & 3.4 \\
\hline 24 & 3.9 & 3.5 \\
\hline 25 & 4.1 & 3.7 \\
\hline
\end{tabular}

\begin{tabular}{|c|c|c|}
\hline \multicolumn{3}{|c|}{ 50th PERCENTILE } \\
\hline Weeks & $\begin{array}{c}\text { Black } \\
\text { population }\end{array}$ & $\begin{array}{c}\text { Caucasian } \\
\text { population }\end{array}$ \\
\hline 26 & 4.3 & 3.9 \\
\hline 27 & 4.4 & 4.1 \\
\hline 28 & 4.7 & 4.3 \\
\hline 29 & 5.0 & 4.5 \\
\hline 30 & 5.2 & 4.7 \\
\hline 31 & 5.4 & 4.9 \\
\hline 32 & 5.7 & 5.0 \\
\hline 33 & 5.8 & 5.2 \\
\hline 34 & 5.9 & 5.4 \\
\hline 35 & 6.0 & 5.6 \\
\hline 36 & 6.2 & 5.8 \\
\hline 37 & 6.3 & 6.0 \\
\hline 38 & 6.4 & 6.2 \\
\hline
\end{tabular}




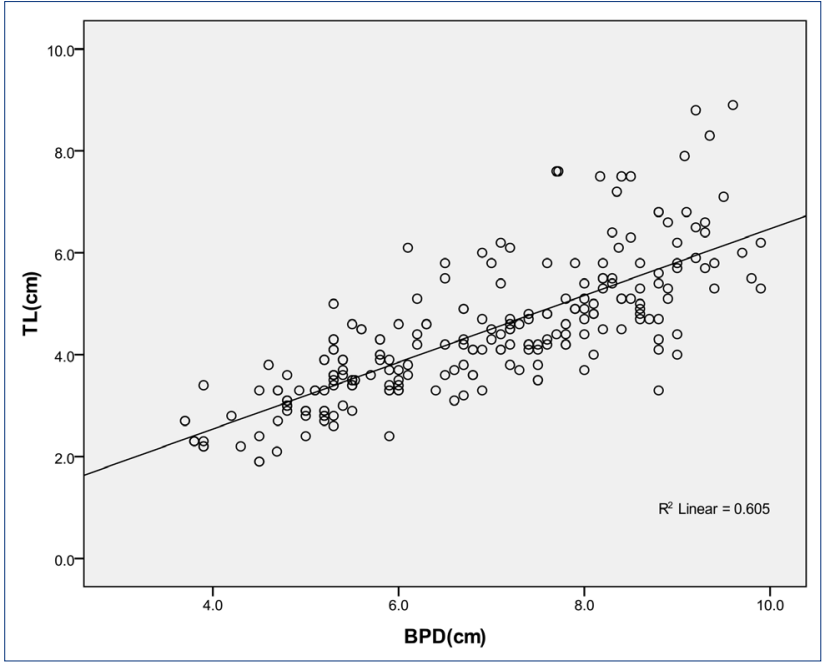

Figure 1. Scatter diagram showing the relationship between TL and BPD. There is a highly positive and statistically significant correlation noted between TL and BPD $\left(r^{2}=0.778, P \leq 0.001\right)$.

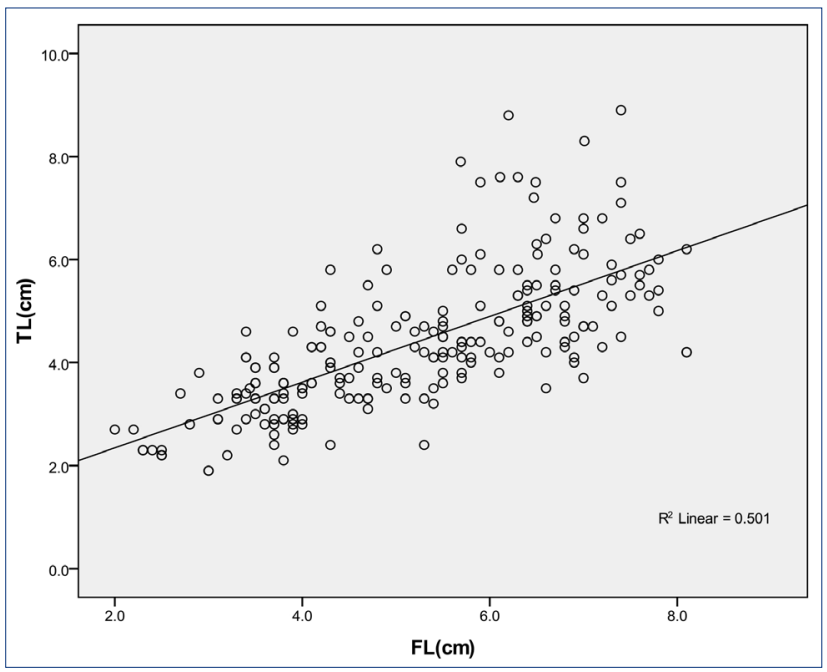

Figure 3. Scatter diagram of TL against FL. There is a highly positive and statistically significant correlation noted between the TL and FL $\left(r^{2}=0.708, P \leq 0.001\right)$.

Figures 1 to 4 show linear and statistically significant correlation between the FTL and BPD, AC, FL and the weeks of gestation. Moreover, the linear relationship between FTL and the weeks of gestation agrees with the findings of Chitkara et al. (13). Therefore, the values of the Caucasian population can be used on black population.

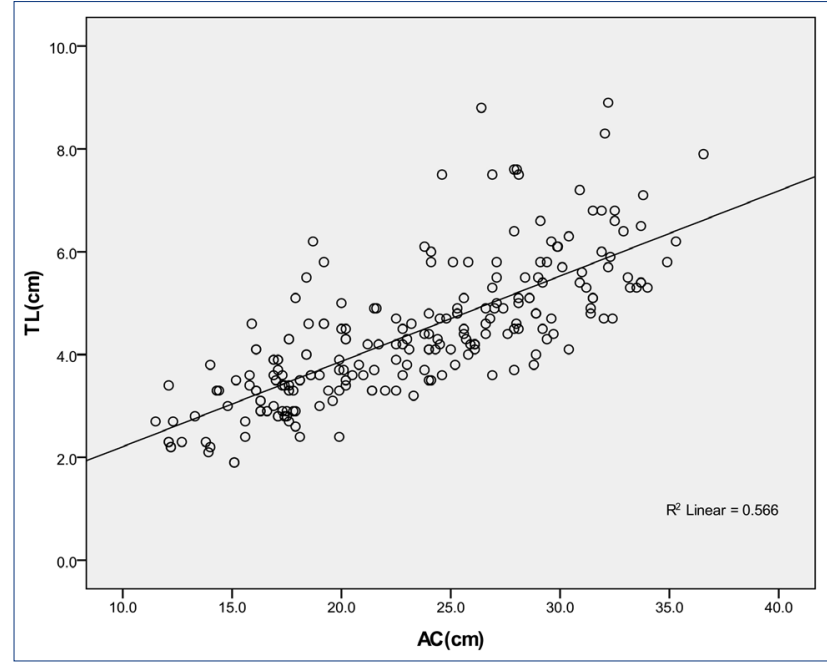

Figure 2. Scatter diagram of TL against AC. There is a highly positive and statistically significant correlation noted between the TL and $A C\left(r^{2}=0.752, P \leq 0.001\right)$.

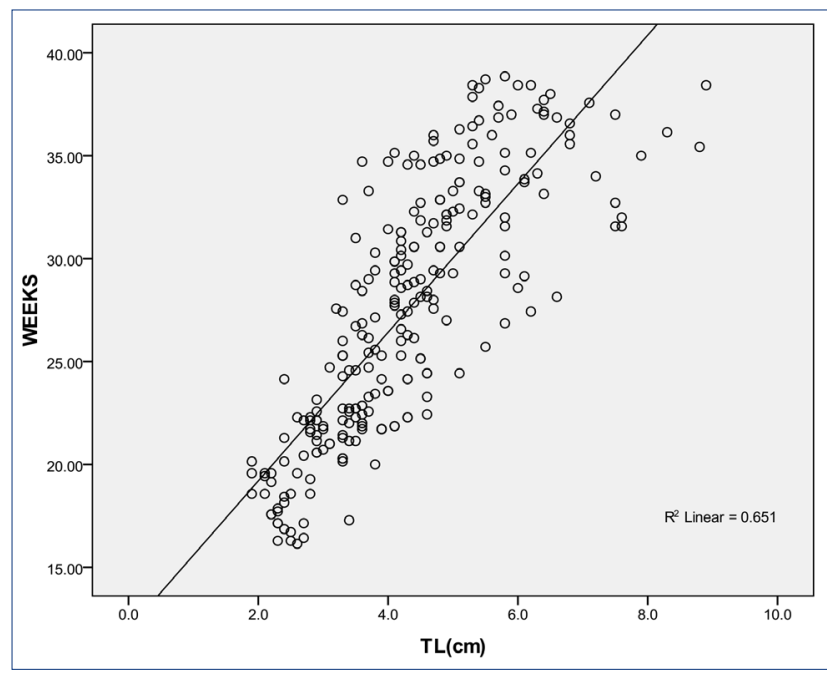

Figure 4. Scatter diagram of TL against weeks of gestation. There is a high and statistically significant correlation noted between the weeks of gestation and the TL $\left(r^{2}=0.807\right.$, $P \leq 0.001)$. 


\section{References}

1. Mongelli M, Wilcox M and Gardosi J. Estimating the date of confinement: ultrasonographic biometry versus certain menstrual dates. Am J Obstet Gynecol. 1996; 174:278 - 281.

2. Kramer MS, McLean FH, Boyd ME, et al. The validity of gestational age estimation by menstrual dating in term, preterm, and postterm gestations. JAMA 1988; 260: 3306- 3308.

3. Pryor J. The identification and long term effects of fetal growth restriction. BJOG: An International Journal of Obstetrics \& Gynaecology, 1997; 104: 1116-1122. doi:10.1111/j.1471-0528.1997.tb10933.x

4. Oechsli FW. Ultrasound fetoscopy and intrauterine growth retardation: two misused fashionable ideas. Paediatr Perinat Epidemiol. 1990; 4(1):8-12.

5. Howards PP, Hertz-Picciotto I, Weinberg CR, et al. Misclassification of Gestational Age in the Study of Spontaneous Abortion. Am J Epidemiol. 2006; 164:1126-1136.

6. MacGregor S and Sabbagha R, Glob. libr. women's med., (ISSN: 1756-2228) 2008; DOI 10.3843/GLOWM.10206

7. Butt K and Lim K. Determination of gestational age by ultrasound. J Obstet Gynaecol Can. 2014; 36(2):171-181. doi: 10.1016/S1701-2163(15)30664-2.

8. Papageorghiou AT, Kemp B, Stones W, et al. and for the International Fetal and Newborn Growth Consortium for the $21^{\text {st }}$ Century (INTERGROWTH-21st). Ultrasound-based gestational age estimation in late pregnancy. Ultrasound Obstet Gynecol. 2016; 48: 719-726. doi:10.1002/ uog. 15894

9. Loughna P, Chitty L, Evans T, et al. Fetal size and dating: charts recommended for clinical obstetric practice. Ultrasound 2009; 17(3):161-167. DOI: 10.1179/174313409X448543.

10. Nwobi IC. Sonographic assessment of foetal thoracic circumference as a predictor of gestational age in Maiduguri, north east Nigeria (MSc. thesis submitted to department of medical radiography and radiological sciences, University of Nigeria). University of Nigeria virtual library 2012.

11. Fong K, Ohlsson A and Zalev A. Fetal thoracic circumference: A prospective cross- sectional study with real-time ultrasound. Am J Obstet Gynecol. 1988; 158(5):1154- 1160.
12. Smith GCS, Smith MFS, McNay MB, et al. The relation between fetal abdominal circumference and birthweight: findings in 3512 pregnancies. BJOG: An International Journal of Obstetrics \& Gynaecology, 1997; 104: 186-190. doi:10.1111/j.1471- 0528.1997.tb11042.x

13. Chitkara U, Rosenberg J, Chervenak FA, et al. Prenatal sonographic assessment of the fetal thorax: normal values. Am J Obstet Gynecol 1987; 156(5): 1069-1074.

14. World Medical Association Declaration of Helsinki Ethical Principles for Medical Research Involving Human Subjects. JAMA 2013; 310(20):2191-2194. Downloaded From: http://jama.jamanetwork.com/ by an American Medical Association User on February 22, 2018. doi:10.1001/jama.2013.281053

15. Shultz SM, Pretorius DH and Budorick NE. Four-chamber view of the fetal heart: demonstration related to menstrual age. J Ultrasound Med. 1994; 13(4):285- 289.

16. Abuhamad A and Chaoui R. Prenatal screening for congenital heart disease. A Practical Guide to Fetal Echocardiography: Normal and Abnormal Hearts. $2^{\text {nd }}$ ed. USA: Lippincott Williams \& Wilkins; 2010. pp. 23- 24

17. Hobbins JC. Fetal biometry. Obstetric Ultrasound: Artistry in Practice. USA: Blackwell Publishing; 2008 pp 39 - 43 ISBN: 978-1-4051-5815-2

18. Robson SC and Chang TC. Measurement of human fetal growth. Cited in; Mark A. Hanson, John A. D. Spencer, Charles H. Rodeck. Fetus and Neonate: Physiology and Clinical Applications: Volume 3, Growth. Great Britain: Cambridge University Press; 1995. pp. 301- 311

19. Marlon I, Ahmed B and Miskovic B. Chapter 5: Basic biometry. Cited in; D’Addario V. Donald School Basic Textbook of Ultrasound in Obstetrics \& Gynecology. $2^{\text {nd }}$ ed. New Delhi: JP Medical Ltd; 2014. pp. 53-58.

20. Kalish RB. Sonographic determination of gestational age. Cited in; D’Addario V. Donald School Basic Textbook of Ultrasound in Obstetrics \& Gynecology. $2^{\text {nd }}$ ed. New Delhi: JP Medical Ltd; 2014 p. 64

21. "Malé, Chata; Wodon, Quentin. 2016. Basic Profile of Child Marriage in Nigeria. World Bank, Washington, DC. (C) World Bank. https://openknowledge.worldbank.org/ handle/10986/24547 License: CC BY 3.0 IGO

22. Mastrobattista J, Pschirer ER, Hamrick A, et al. Humerus length evaluation in different ethnic groups. J Ultrasound Med 2004; 23: 227-231. 


\section{ULTRAZVUČNA PROCJENA FETALNE PRSNE DULJINE KAO PREDIKTOR GESTACIJSKE DOBI KOD NIGERIJSKE POPULACIJE}

\section{Sažetak}

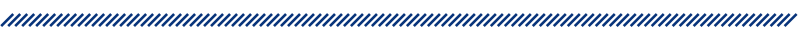

Uvod: Ultrazvučni uređaji koji se upotrebljavaju u našem području koriste se softverskim programom koji sadrži normativne vrijednosti koje ne odgovaraju domaćem stanovništvu. Nadalje, kako trudnoća odmiče, točnost većine biometrijskih parametara u predviđanju gestacijske dobi varira zbog rasnih morfoloških razlika te se povećava mogućnost pogreške. Stoga postoji i potreba za ovim istraživanjem.

Svrha istraživanja: Utvrditi ultrazvučne normativne vrijednosti fetalne prsne duljine za lokalnu populaciju (pripadnici crne rase) i usporediti s vrijednostima koje se primjenjuju za pripadnike bijele rase.

Materijali i metode: Žene trudne s jednim djetetom, koje su zanijele prirodnim putem i koje su zadovoljavale pojedinačne kriterije za uključivanje u istraživanje, redom su uključivane u istraživanje. Prilikom istraživanja u obzir je uzeta i Helsinška deklaracija iz 1975. godine. Prospektivno presječno istraživanje provedeno je u Saveznom medicinskom centru Azare, Bauchi. Istraživanje je obuhvatilo 253 žene koje su se bile trudne između 16 i 38 tjedana. 2D ultrazvuk primijenjen je za mjerenje fetalne prsne duljine (od korijena vrata do dijafragme) na razini presjeka kroz četiri srčane komore.

Rezultati: Dobivene su normalne vrijednosti fetalne prsne duljine koje imaju linearnu i statistički značajnu povezanost $s$ tjednima trudnoće $(r 2=0,81, P \leq 0,001)$. Fetalna prsna duljina ima stopu rasta od 0,182 cm tjedno.

Zaključak: Nema statistički značajne razlike između vrijednosti fetalne prsne duljine za stanovništvo na kojem se vršilo istraživanje (crna populacija) i za bijelu populaciju. Stoga se vrijednosti fetalne prsne duljine koje se primjenjuju za bijelu populaciju mogu primjenjivati za valjanu procjenu gestacijske dobi kod crne populacije. Prediktivna je jednadžba za izračun gestacijske dobi: $y=3,61 x+11,95$, gdje je $y=$ gestacijska dob u tjednima $\mathrm{i} x=$ prsna duljina.

Ključne riječi: fetalna prsna duljina, gestacijska dob, prikaz presjeka kroz četiri srčane komore, ultrazvuk 